\title{
STABLE ISOTOPES OF HYDROGEN AND OXYGEN IN RUNOFF WATERS IN NORTHWESTERN SICHUAN OF SOUTHWESTERN CHINA
}

\author{
SHI, Z. ${ }^{1}-$ PAN, P. ${ }^{1 *}-$ WANG, X. ${ }^{1}-$ JIN, L. ${ }^{2}-$ LIU, M. ${ }^{1}-$ LI, A. ${ }^{1}-$ XU, J. ${ }^{1}$ \\ ${ }^{1}$ Department of Geochemistry, Chengdu University of Technology \\ 610059 Chengdu, Sichuan, China \\ ${ }^{2}$ Sichuan Institute of Geological Survey \\ 610081 Chengdu, Sichuan, China \\ *Corresponding author \\ e-mail: Pujing.Pan@outlook.com; phone: +1-613-686-1312
}

(Received $1^{\text {st }}$ Jul 2017; accepted $28^{\text {th }}$ Sep 2017)

\begin{abstract}
In studying the hydro-ecological conditions in northwestern Sichuan of southwestern China, an area at the edge of the Qinghai-Tibet Plateau, stream waters were extensively sampled and analyzed for the stable hydrogen and oxygen isotope ratios $\left(\delta^{2} \mathrm{H}\right.$ and $\left.\delta^{18} \mathrm{O}\right)$ which are often excellent indicators for a water body genesis and evolvement. The heavy isotopes of hydrogen and oxygen were found to be, in general, gradually depleted from east to west in the region; the phenomenon is attributed mainly to continentality based on the assumption that the isotopic signatures in the precipitations were preserved in the stream waters. The $\delta^{2} \mathrm{H}$ and $\delta^{18} \mathrm{O}$ data from the Yangtze River basin were found to fall well on the global meteoric water line (GMWL), indicative of the fact that the runoff waters in this basin were primarily of meteoric origin with a regional weak evaporation prevailing during our sampling time. However, the isotopic data from a relatively small part of the area in the north belonging to the Yellow River basin are characterized by the appreciably flatter slope of the local water isotope line and lower dexcess values, suggesting that the steam waters had undergone significant evaporation due to kinetic fractionations of isotopes in a more arid climate. The stable isotope data were also applied in calculating water mixing for some selected rivers. This study represents a snapshot study of the area's hydro-ecology; more systematic studies are required in better understanding the seasonal hydrological variations.
\end{abstract}

Keywords: meteoric water, hydro-ecology, $\delta^{2} H$ and $\delta^{18} \mathrm{O}$, three-river headwaters (TRH), southwestern China

\section{Introduction}

The hydro-ecological conditions of the Qinghai-Tibet Plateau are of critical importance to several Asian countries including a large part of China. The three-river headwaters (TRH) region, located in southern Qinghai province $\left(31^{\circ} 39^{\prime}-36^{\circ} 16^{\prime} \mathrm{N}\right.$, $89^{\circ} 24^{\prime}-102^{\circ} 23^{\prime} \mathrm{E}$ ), is known as China's water tower where China's three largest rivers (among the world's largest ones) originate. The Big Three, i.e., the Yangtze River, the Yellow River and the Lancang River, obtain, respectively, 25\%, 50\% and 15\% of their water from the TRH region (Zhao et al., 2010). Because of the fragile primordial ecosystem and due to the increased anthropogenic activities during the past several decades, the eco-environmental problems in the region such as grassland degradation, wetland shrinkage and soil erosion started to accelerate since the 1980's and presently serious and immediate attentions are called for ( $\mathrm{Li}$ et al., 2012; Gao et al., 2013). Li et al. (2012) found that the water loss due to evapotranspiration in the TRH region 
increased $11.6 \mathrm{~mm}$ annually between 1980 and 2000, meanwhile exhibiting an accelerating trend. It is therefore important to understand the hydro-ecological system of the region in order to conserve and restore its environmental conditions. However, this vast area is generally not easily accessible due to high altitude, harsh climate, extreme remoteness and lack of roads.

The northwestern Sichuan area studied in this work, with gradually decreasing elevations southeasterly, forms the easternmost part of the Qinghai-Tibet Plateau. This area can be divided into two sub-regions: the Northwestern Sichuan Plateau and the Southwestern Sichuan Mountainous Terrain (Figure 1). The former is characterized by vast and hummocky plateaus with high elevations (3,500 to 4,000 $\mathrm{m}$ or higher); the latter consists of numerous high mountain ranges separated by deep valleys with elevation differentials as much as 3,000 m, known generically as the Hengduan Mountains. The river systems and wetlands in the region are intrinsically connected with those in the upper part of the TRH region. These wetlands provide many important ecological services such as lessening the greenhouse effect by taking up and storing carbon, and are invaluable environmental and ecologic resources (Avis et al., 2011). The hydro-ecological condition of this region is an important integral part of the TRH regional ecology; a thorough understanding of this region may hold the key for the entire TRH region. These wetlands have experienced significant degradation over the past 4 decades and have shrunk by some $29 \%$, and the wetland ecosystems are increasingly fragmented at an accelerated pace (Li et al., 2012; Qi and Li, 2007; Wang et al., 2007) mainly due to the increased anthropogenic activities in the region (Li et al., 2012). In order to stabilize and possibly reverse the ecological conditions of the region, the regional hydrology including the sources of the precipitations, the general water cycle processes of the drainage basins must be understood.

The stable isotopes of oxygen $\left({ }^{18} \mathrm{O}\right)$ and hydrogen $\left({ }^{2} \mathrm{H}\right)$ can be accurately determined (usually as isotope ratios) with modern technologies (Richelle et al., 2004; Bowen et al., 2005a; Paul et al., 2007), and have become some of the most widely used tracers in drainage basin hydrological studies (Clark and Fritz, 1997; Kendall and McDonnell, 1998; Buttle and McDonnell, 2004). In particular, stable isotope fractionation during precipitation processes are well understood, both ${ }^{18} \mathrm{O}$ and ${ }^{2} \mathrm{H}$ in precipitations vary spatially and temporally depending on the moisture sources and the environmental conditions (e.g., relative humidity and temperature) during cloud formation and rainfall. The isotope ratios in precipitations, their seasonal variations at a given location, and their distribution over a region often reflect the relevant meteorological and geographical conditions such as local temperature and temperature variation, distance from the coast (continentality), latitude and altitude, amount of precipitation and duration (Clark and Fritz, 1997).

Due to their spatial and temporal variability in meteoric waters, these isotope ratios ( $\delta^{2} \mathrm{H}$ and $\delta^{18} \mathrm{O}$ values) have been used to identify sources of water such as atmospheric moisture (Liu et al., 2010; Sjostrom and Welker, 2009; Vachon et al., 2010; Welker, 2000), groundwater recharge (Abbott et al., 2000; Blasch and Bryson, 2007; Adomako 
et al., 2010), and plant water uptake (Brooks et al., 2010). In this work, the surface stream waters in the northwestern Sichuan region, an area covering part of both the Yangtze River and the Yellow River drainage basins (divided by the Chazhengliangzi Mountain in Hongyuan, Sichuan) were extensively sampled and analyzed for $\delta^{2} \mathrm{H}$ and $\delta^{18} \mathrm{O}$. Most rivers in the region including the Minjiang, Jialing, Fuhe and Dadu flow from north to south or from west to east to the Yangtze River (Yangtze River drainage basin), whereas the Heihe and Baihe rivers from south to north to the Yellow River (Yellow River drainage basin). The main objective of this study is to enhance our understanding of the regional hydrology of the study area through characterizing the isotopic variation patterns of the runoff waters and identifying the main influential factors including the geographical and meteorological parameters. As the TRH region is difficult to access and its hydrology study is still at a relatively early stage, the current work may help fill some of the gaps in the study of the hydrological-ecological conditions of the entire TRH region.

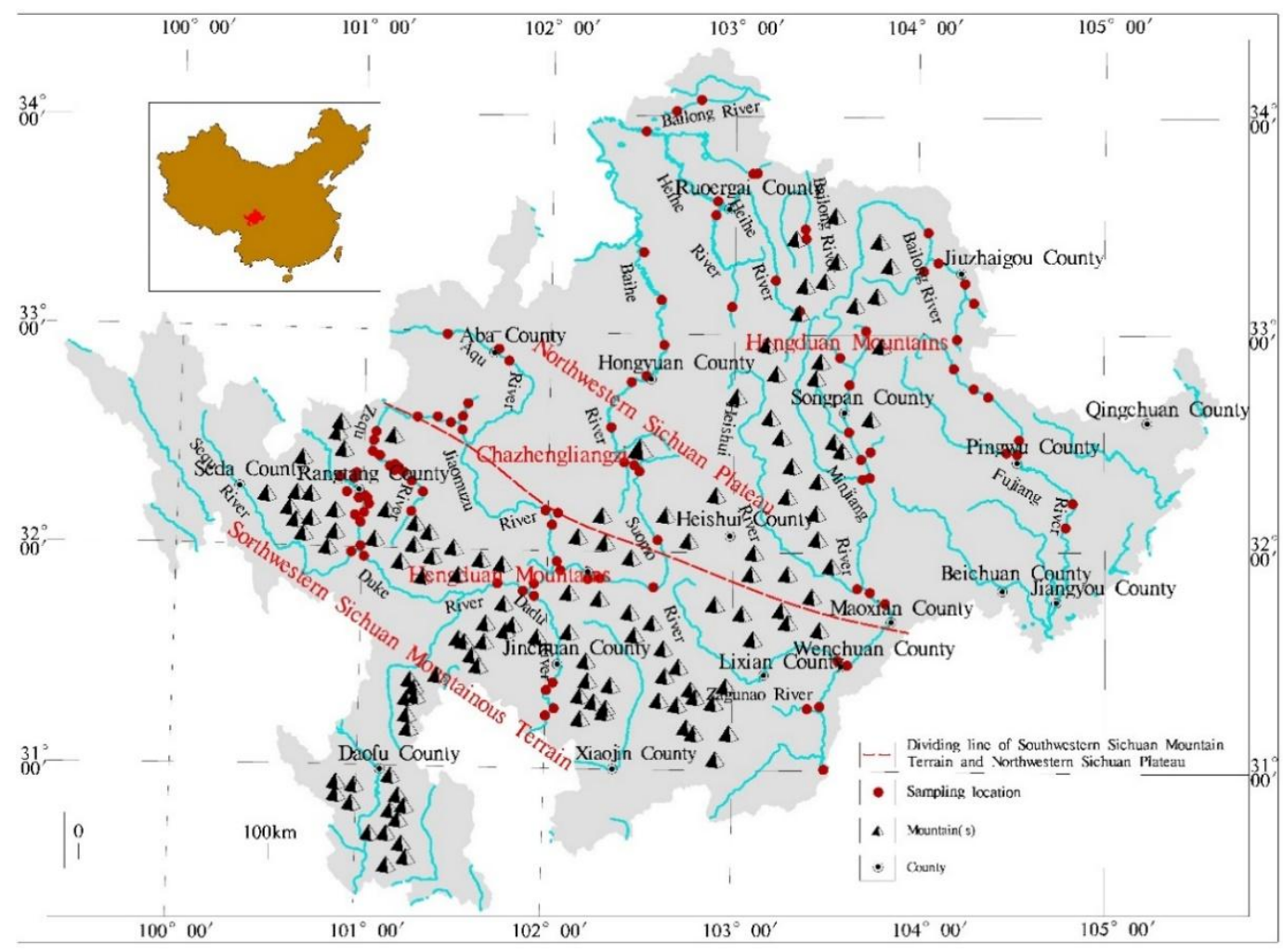

Figure 1. Map of the main rivers in the study area with sample locations

\section{Materials and methods}

\section{Study area}

The study area is at the edge of the Qinghai-Tibet Plateau and is generally known as the Northwestern Sichuan Plateau. Water samples were taken from locations in 28 counties: 13 alpine counties including Rangtang, Aba, Songpan, Ruoergai and 
Hongyuan in Aba Prefecture, and 18 mountainous counties including Seda in Ganzi Prefecture, Wangcang in Guangyuan City, Hanyuan in Ya'an City, and Pingwu in Mianyang City, covering a total area of $149,000 \mathrm{~km}^{2}$. In total 86 stream water samples were collected for $\delta^{2} \mathrm{H}$ and $\delta^{18} \mathrm{O}$ analysis from 7 river systems (Table 1). Owning to logistic difficulties, the sample campaign had to be conducted in two consecutive summers of 2010 and 2011. Approximately half of the samples were taken in July of 2010 and half in July and August of 2011. The climatic conditions of the sampling area from June to August are summarized and compared in Table 2 for 2010 and 2011 (data were downloaded from Tutiempo Network website, http://en.tutiempo.net/). From Table 2 , it is clear that the climatic conditions of the area were closely similar between 2010 and 2011 during the sampling months. It is noted that August 2011 appeared to be drier than August 2010; however, this difference would not impact our discussions because the dry season essentially occurred after our sampling campaign.

Table 1. Number of river water samples taken from various river catchments

\begin{tabular}{c|c}
\hline River Catchment & No. of Samples \\
\hline Fujiang & 8 \\
Baishui & 6 \\
Heihe & 7 \\
Bailong & 4 \\
Minjiang & 16 \\
Duke & 13 \\
Zequ & 8 \\
Baihe & 6 \\
Suomo & 5 \\
Jiaomuzu & 13 \\
\hline Sum & 86 \\
\hline
\end{tabular}

Table 2. Comparison of summer climatic conditions between 2010 and 2011 at selected locations in the study area

\begin{tabular}{|c|c|c|c|c|c|c|}
\hline & \multicolumn{2}{|c|}{ Average temperature $\left({ }^{\circ} \mathrm{C}\right)$} & \multicolumn{2}{|c|}{ Precipitation $(\mathrm{mm})$} & \multicolumn{2}{|c|}{ Number of rainy days } \\
\hline & 2010 & 2011 & 2010 & 2011 & 2010 & 2011 \\
\hline \multicolumn{7}{|c|}{ Songpan, 32.65N 103.56E, Elevation $2852 \mathrm{~m}$} \\
\hline June & 12.9 & 14.1 & 125.2 & 113.27 & 23 & 21 \\
\hline July & 16.9 & 15.0 & 101.1 & 120.65 & 20 & 19 \\
\hline August & 16.4 & 15.1 & 118.39 & 39.36 & 17 & 12 \\
\hline \multicolumn{7}{|c|}{ Seda, 32.28N 100.33E, Elevation 3896 m } \\
\hline June & 9.5 & 9.6 & 153.67 & 189.22 & 25 & 22 \\
\hline July & 12.4 & 10.2 & 65.78 & 197.63 & 16 & 25 \\
\hline August & 10.8 & 9.9 & 99 & 62.98 & 19 & 12 \\
\hline \multicolumn{7}{|c|}{ Daofu, 30.98N 101.11E, Elevation $2959 \mathrm{~m}$} \\
\hline June & 15.4 & 15.8 & 157.21 & 118.12 & 22 & 21 \\
\hline July & 17.9 & 15.9 & 111.76 & 121.66 & 17 & 20 \\
\hline August & 16.9 & 16.2 & 108.2 & 63.25 & 17 & 9 \\
\hline
\end{tabular}




\begin{tabular}{ccccccc}
\hline \multicolumn{7}{c}{ Ganzi, $31.61 \mathrm{~N}$ 100E, Elevation 3394 m } \\
June & 13.5 & 13.7 & 157.99 & 121.91 & 26 & 23 \\
July & 16.2 & 14 & 71.65 & 138.69 & 19 & 23 \\
August & 15.3 & 13.8 & 89.9 & 71.36 & 21 & 13 \\
\hline \multicolumn{7}{c}{ Ma'erkang, 31.9N 102.23E, Elevation 2666 m } \\
June & 15.1 & 15.4 & 155.96 & 169.17 & 27 & 21 \\
July & 17.7 & 15.5 & 180.6 & 157.22 & 24 & 22 \\
August & 16.9 & 16.5 & 145.31 & 42.42 & 24 & 11 \\
\hline
\end{tabular}

Data from: http://en.tutiempo.net/

\section{Methods}

The sampling locations are listed in Table 3 and shown on the map in Figure 1. We have exercised rigorous and systematic quality assurance measures in the field at various levels to ensure the samples were taken and labeled appropriately. We conducted the sample taking following strictly the procedures set out in the Quality Assurance Manual for Environmental Water Monitoring (Zhang, 1994). The water samples were taken at a depth of a few centimeters below the water surface to ensure that the river water was fully mixed to avoid any potential surface isotope fractionation effect due to evaporation. When sampling from a water body where two streams met, samples were taken only in the fully mixed zone, $200 \mathrm{~m}$ or further downstream from the meeting point. During sampling, observations of water quality, river flow rate, vegetation on both banks, rock composition and geological features were also made. More details on sampling was described elsewhere (Shi et al., 2016).

Table 3. Summary of measured sample isotopic data ( $\delta^{2} H$ and $\delta^{18} O$ values), associated location, and other information

\begin{tabular}{|c|c|c|c|c|c|c|}
\hline Catch. & Location & $\operatorname{Elev}(\mathrm{m})$ & $\operatorname{Temp}\left({ }^{\circ} \mathrm{C}\right)$ & $\delta^{2} \mathbf{H}$ & $\delta^{18} O$ & d-excess \\
\hline \multirow{8}{*}{  } & $5 \mathrm{~km}$ north of Xiangyanzhen & 648 & 25.0 & -65.5 & -9.74 & 12.4 \\
\hline & $2 \mathrm{~km}$ south of Pingwubazi & 716 & 25.0 & -66.8 & -9.97 & 13.0 \\
\hline & $3 \mathrm{~km}$ north of Pingwu & 744 & 17.1 & -64.7 & -9.84 & 14.1 \\
\hline & $\begin{array}{c}1.5 \mathrm{~km} \text { from Dapingli near } \\
\text { Huanglong }\end{array}$ & 899 & 17.3 & -64.7 & -9.83 & 13.9 \\
\hline & $\begin{array}{l}2 \mathrm{~km} \text { from Liangheshui } \\
\text { (Jiuzhaigou direction) }\end{array}$ & 890 & 18.2 & -65.3 & -9.76 & 12.7 \\
\hline & $\begin{array}{l}500 \text { m downstream from } \\
\text { Hua'neng Hydro Station }\end{array}$ & 1121 & 12.6 & -70.4 & -10.54 & 13.9 \\
\hline & Near Shuiniujia, Baima Township & 2110 & 16.6 & -65.8 & -9.68 & 11.6 \\
\hline & $\begin{array}{l}\text { Yangdong River Divide } \\
\text { downstream near source }\end{array}$ & 2387 & 13.2 & -67.3 & -10.07 & 13.3 \\
\hline \multirow{3}{*}{ 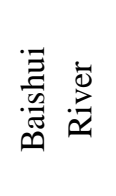 } & At Wujiao, Jiuzhaigou & 1598 & 16.4 & -66.7 & -10.18 & 14.8 \\
\hline & $\begin{array}{l}2 \mathrm{~km} \text { from Shuanghe (Wenxian } \\
\text { direction) }\end{array}$ & 1430 & 17.1 & -77.0 & -10.96 & 10.7 \\
\hline & $2.5 \mathrm{~km}$ south of Jiuzhaigou & 1400 & 17.6 & -75.8 & -11.07 & 12.8 \\
\hline
\end{tabular}




\begin{tabular}{|c|c|c|c|c|c|c|}
\hline & $\begin{array}{l}1 \mathrm{~km} \text { upstream Baihe Township } \\
\text { (Heihe) }\end{array}$ & 1562 & 14.5 & -76.5 & -11.16 & 12.8 \\
\hline & $\begin{array}{c}\text { Under Yanlicun Bridge, Baihe } \\
\text { Township }\end{array}$ & 1789 & 13.8 & -76.7 & -11.19 & 12.8 \\
\hline & $\begin{array}{l}5 \mathrm{~km} \text { upstream from Jiuzhaigou } \\
\text { mouth }\end{array}$ & 2179 & 11.3 & -78.7 & -11.49 & 13.2 \\
\hline \multirow{7}{*}{ 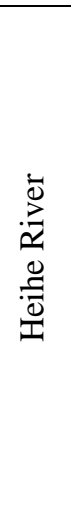 } & $\begin{array}{c}10 \mathrm{~km} \text { north of Songpan and } \\
\text { Ruoergai border }\end{array}$ & 3693 & 19.3 & -83.9 & -11.55 & 8.5 \\
\hline & $25 \mathrm{~km}$ southeast of Rouergai & 3522 & 20.0 & -83.7 & -11.32 & 6.8 \\
\hline & $\begin{array}{c}1 \mathrm{~km} \text { west of Heihe divisional } \\
\text { ranch }\end{array}$ & 3429 & 19.9 & -80.8 & -10.36 & 2.1 \\
\hline & $\begin{array}{l}\text { Creek, front of Axi Government } \\
\text { Building }\end{array}$ & 3493 & 19.5 & -83.6 & -11.35 & 7.2 \\
\hline & $4 \mathrm{~km}$ northwest of Ruoergai & 3437 & 18.0 & -81.7 & -10.23 & 0.2 \\
\hline & Heihe divisional ranch & 3442 & 21.2 & -80.5 & -10.03 & -0.3 \\
\hline & Maiwaxiang, Hongyuan & 3555 & 21.6 & -89.0 & -12.67 & 12.4 \\
\hline \multirow{4}{*}{ 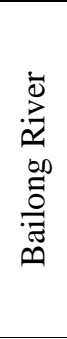 } & $\begin{array}{c}2 \mathrm{~km} \text { downstream Jiangza } \\
\text { township }\end{array}$ & 3019 & 14.8 & -79.7 & -11.21 & 10.0 \\
\hline & $\begin{array}{l}\text { Upstream Hongxing township, } \\
\text { near source of Bailong River }\end{array}$ & 3186 & 14.1 & -81.0 & -11.15 & 8.2 \\
\hline & In Baozuo Township yard & 3022 & 14.1 & -83.0 & -11.78 & 11.3 \\
\hline & $\begin{array}{c}500 \mathrm{~m} \text { downstream from Baozuo } \\
\text { Township yard }\end{array}$ & 3009 & 20.0 & -83.8 & -11.85 & 11.0 \\
\hline \multirow{15}{*}{ 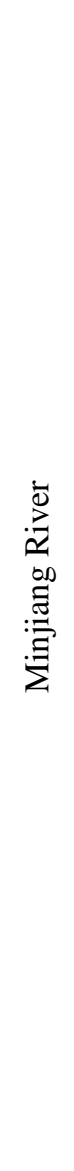 } & $\begin{array}{l}\text { 8-10 km downstream from } \\
\text { Minjiang source }\end{array}$ & 3316 & 13.6 & -84.7 & -12.16 & 12.5 \\
\hline & $\begin{array}{l}5 \mathrm{~km} \text { from Chuanzhusi (Ruoergai } \\
\text { direction) } \\
\end{array}$ & 3021 & 14.8 & -83.3 & -11.79 & 11.1 \\
\hline & $\begin{array}{l}8 \mathrm{~km} \text { downstream from } \\
\text { Chuanzhusi }\end{array}$ & 2921 & 15.8 & -86.2 & -12.25 & 11.8 \\
\hline & Munigou mouth & 2706 & 13.0 & -85.6 & -12.16 & 11.7 \\
\hline & $\begin{array}{l}\text { Under bridge near Daxing'gou } \\
\text { mouth }\end{array}$ & 2581 & 14.5 & -89.1 & -12.65 & 12.1 \\
\hline & Minjiang mainstream & 2568 & 17.1 & -85.3 & -11.99 & 10.6 \\
\hline & Minjiang mainstream & 2491 & 17.1 & -86.5 & -12.33 & 12.2 \\
\hline & Mouth of Xiaohegou & 2487 & 19.6 & -81.8 & -11.56 & 10.8 \\
\hline & Downstream from Heishuihe & 1650 & 18.4 & -87.1 & -12.30 & 11.3 \\
\hline & $\begin{array}{c}\text { Minjiang mainstream, } \\
\text { downstream of hydro station }\end{array}$ & 1653 & 17.6 & -81.7 & -11.69 & 11.8 \\
\hline & $\begin{array}{l}\text { Minjiang mainstream, under } \\
\text { Juanmenxiang Bridge }\end{array}$ & 1649 & 20.5 & -84.5 & -12.11 & 12.4 \\
\hline & $\begin{array}{c}\text { Minjiang mainstream, behind } \\
\text { Zhongxing } \\
\end{array}$ & 1353 & 19.8 & -83.4 & -11.90 & 11.8 \\
\hline & $\begin{array}{c}\text { Upstream of Zagu'nao River } \\
\text { Hydro Station }\end{array}$ & 1384 & 16.6 & -90.6 & -12.69 & 10.9 \\
\hline & $\begin{array}{l}\text { Minjiang mainstream at Yinxing } \\
\text { township }\end{array}$ & 991 & 18.7 & -85.0 & -11.98 & 10.8 \\
\hline & Shaotang River tributary & 898 & 24.5 & -83.7 & -12.07 & 12.9 \\
\hline
\end{tabular}




\begin{tabular}{|c|c|c|c|c|c|c|}
\hline & Minjiang mainstream & 711 & 21.8 & -83.1 & -11.96 & 12.6 \\
\hline \multirow{13}{*}{ 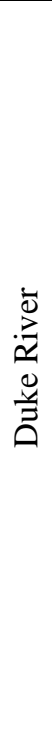 } & Gangmudarewo Village & 3298 & 13.4 & -98.3 & -14.02 & 13.9 \\
\hline & Rangkegare Village & 3253 & 15.3 & -98.7 & -14.01 & 13.4 \\
\hline & Gangmudake Village & 3205 & 12.9 & -97.7 & -13.76 & 12.4 \\
\hline & Rangtangdamuda Village & 3277 & 13.0 & -98.8 & -13.80 & 11.6 \\
\hline & Sequ River at Heiqiao & 3008 & 15.5 & -107.5 & -14.87 & 11.4 \\
\hline & Heiqiao, Rangtang & 3007 & 14.0 & -99.1 & -13.97 & 12.6 \\
\hline & Ergewu Village, Heiqiao & 3009 & 14.8 & -101.2 & -14.22 & 12.6 \\
\hline & Guanyinqiao, Jinchuan & 2078 & 14.0 & -103.3 & -14.46 & 12.4 \\
\hline & Baiwan, Ma'erkang & 2300 & 17.7 & -101.0 & -14.41 & 14.3 \\
\hline & Gangmudarewo Village & 3382 & 9.1 & -99.8 & -13.85 & 11.0 \\
\hline & Gangmudarewo Village & 3341 & 12.3 & -100.4 & -14.11 & 12.6 \\
\hline & Rangkegare Village & 3264 & 9.6 & -107.4 & -14.71 & 10.3 \\
\hline & Gangmuda'angke Village & 3193 & 12.0 & -106.3 & -14.86 & 12.6 \\
\hline \multirow{8}{*}{$\begin{array}{l}\bar{D} \\
\stackrel{2}{\alpha} \\
\vec{D} \\
\text { N }\end{array}$} & $\begin{array}{c}\text { Xumuda Village, Shangrangtang } \\
\text { township }\end{array}$ & 3480 & 13.0 & -100.7 & -13.96 & 11.0 \\
\hline & Upper Rangtang & 2869 & 13.1 & -100.9 & -14.09 & 11.8 \\
\hline & Middle Rangtang & 3489 & 13.7 & -101.1 & -14.10 & 11.8 \\
\hline & $\begin{array}{c}\text { Yigenmenduo Village, Middle } \\
\text { Rangtang }\end{array}$ & 3412 & 13.4 & -101.8 & -14.21 & 12.0 \\
\hline & Gaduo, Rangtang & 3480 & 14.9 & -100.1 & -14.23 & 13.8 \\
\hline & South Muda, Rangtang & 3362 & 15.9 & -100.3 & -13.98 & 11.6 \\
\hline & Rongmuda Village & 3292 & 18.5 & -100.5 & -14.32 & 14.1 \\
\hline & Yigenmenduo Village & 3411 & 13.2 & -101.5 & -13.44 & 6.0 \\
\hline \multirow{11}{*}{ 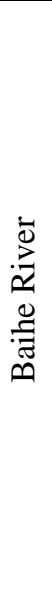 } & Xigou, Hongyuan & 3635 & 11.0 & -94.1 & -13.29 & 12.2 \\
\hline & Anqu, Hongyuan & 3519 & 13.5 & -92.5 & -13.46 & 15.2 \\
\hline & Hongyuan & 3491 & 15.3 & -96.8 & -13.55 & 11.6 \\
\hline & Baihe at Tangke & 3463 & 17.3 & -87.6 & -11.81 & 6.9 \\
\hline & $5 \mathrm{~km}$ upstream Waqie & 3462 & 16.4 & -88.8 & -12.16 & 8.5 \\
\hline & Baihe, upstream Amu Township & 3477 & 17.8 & -87.7 & -11.90 & 7.4 \\
\hline & Rangkou, Hongyuan & 3574 & 11.5 & -96.3 & -13.39 & 10.9 \\
\hline & Laomaokang Village & 3225 & 10.8 & -95.9 & -13.21 & 9.8 \\
\hline & Suomo, Ma'erkang & 2530 & 10.8 & -100.1 & -13.71 & 9.6 \\
\hline & Ma'erkang & 2645 & 11.4 & -96.5 & -13.98 & 15.3 \\
\hline & Songgang, Ma'erkang & 2495 & 13.3 & -96.1 & -13.83 & 14.5 \\
\hline \multirow{7}{*}{ 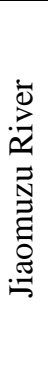 } & Jia'erduo (Aqu River) & 3430 & 17.5 & -84.1 & -11.93 & 11.4 \\
\hline & Anjiang (Aqu River) & 3248 & 17.8 & -87.1 & -12.38 & 11.9 \\
\hline & Kehe Village (Aqu River) & 3070 & 15.4 & -91.3 & -12.73 & 10.5 \\
\hline & Kuasha, Aba & 2985 & 15.4 & -92.9 & -12.91 & 10.4 \\
\hline & Kuasha (Aqe River) & 2985 & 13.5 & -85.7 & -12.20 & 12.0 \\
\hline & Kuasha (Ma'erqu River) & 2985 & 15.0 & -86.2 & -12.38 & 12.9 \\
\hline & Gabo, Ma'erkang & 2536 & 15.4 & -92.1 & -13.01 & 12.0 \\
\hline
\end{tabular}




\begin{tabular}{c|c|c|c|c|c|c}
\hline Gabo & 2496 & 15.3 & -96.6 & -13.84 & 14.1 \\
\cline { 2 - 6 } & Jiaomuzu, Ma'erkang & 2500 & 15.8 & -92.0 & -13.09 & 12.7 \\
\cline { 2 - 6 } & Baiwan, Ma'erkan & 2344 & 16.1 & -92.0 & -13.11 & 12.9 \\
\cline { 2 - 6 } & Shuangjiangkou, Ma'erkang & 2318 & 17.2 & -99.5 & -13.82 & 11.1 \\
\hline Kehe Village & 3064 & 20.0 & -100.1 & -13.83 & 10.6 \\
\cline { 2 - 6 } & Gabo & 2469 & 13.1 & -96.7 & -13.95 & 15.0 \\
\hline
\end{tabular}

Notes : Catch. - Catchment; Elev - Elevation; Temp - Temperature

Hydrogen and oxygen isotopes $\left(\delta^{2} \mathrm{H}\right.$ and $\delta^{18} \mathrm{O}$ values) were determined by the Sichuan Provincial Key Isotope Laboratory at the Chengdu University of Technology, using high temperature conversion elemental analysis - isotopic ratio mass spectrometry (TC/EAIRMS) with the instruments supplied by Thermo Fisher (TM Flash 2000 coupled with a mass spectrometer, MAT-253). The accuracy of the isotopic ratio analysis relative to the Vienna-Standard Mean Ocean Water (VSMOW) was determined to be $\pm 0.2 \%$ and $\pm 2.0 \%$ for $\delta^{18} \mathrm{O}$ and $\delta^{2} \mathrm{H}$, respectively. Water samples were analyzed without pretreatment. For more details about the analytical procedure used, the reader is referred to Burgoyne and Hayes (1998), Hoefs (2009), and Richelle et al. (2004).

\section{Results and discussion}

\section{$\delta^{18} \mathrm{O}, \delta^{2} \mathrm{H}, \mathrm{d}$-excess and local meteoric water line (LMWL)}

The measured stable hydrogen and oxygen isotope $\delta$-values are presented in Table 3 together with the associated information of sample locations and the relevant river catchments/drainage basins. Because altitude and temperature are two of the most important parameters governing isotopic fractionations in precipitation (see discussions below), these two parameters were therefore also measured and are included in Table 3. Since the climatic conditions in 2010 and 2011 were very similar during the sampling times (Table 2), the measured isotopic data were analyzed and discussed without distinction of the sampling year. The parameter d-excess can convey additional information about the water bodies studied, therefore the derived d-values are also tabulated in Table 3.

The measured $\delta^{18} \mathrm{O}$ and $\delta^{2} \mathrm{H}$ values range from, respectively, $-14.87 \%$ to $-9.68 \%$ and $107.5 \%$ to $-64.7 \%$ for the water samples taken from the various river systems in the study area. When the data are plotted in a $\delta^{2} \mathrm{H}-\delta^{18} \mathrm{O}$ diagram as shown in Figure 2, the data points align well with the GMWL as defined by Craig (1961), suggesting that the area's stream water was likely of meteoric origin primarily. Recently, Liu et al. (2014) studied and reported the isotopic compositions of precipitations in China based on the data collected from 29 stations including two within the present study area: 1. Maoxian (MX), elevation $1,826 \mathrm{~m}$, located near the southeast border of the study area, and 2. Gonggashan (GG), elevation 2,950 m, located at the southwest border of the study area. 
The reported $\delta^{2} \mathrm{H}$ values are from -83.3 to 8.5 with a mean of -49.5 for MX, from -147.8 to 1.4 with a mean of -76.5 for $\mathrm{GG}$; and $\delta^{18} \mathrm{O}$ from -11.98 to 0.31 with a mean of -7.77 for MX, from -19.50 to -2.35 with a mean of -10.82 for GG. These data compare very well with our data of samples from the same general areas (see Figure 2 and Table 2 for data from Fujiang River and Duke River, respectively) considering that the data by Liu et al. (2014) are monthly precipitation-weighted averages while our data are one-time values. Therefore, it is assumed in this work that the samples taken from the streams represent the local precipitations in terms of isotopic compositions. Our data span relatively narrow ranges when compared to the China national data of $\delta^{18} \mathrm{O}(-29.47$ to $-2.75 \%)$ and $\delta^{2} \mathrm{H}(-$ 229.6 to $45.4 \%$ ) (Liu et al., 2014). This is, perhaps, expected due to the fact that the area is located in the Asian monsoon region and our sampling times coincided with the monsoon prime times (Liu et al., 2014). The area was receiving rainfalls almost daily during our sampling times with the total precipitations of $100-200 \mathrm{~mm} / \mathrm{month}$. As the sampling was conducted during the warmest time of a year, the melting of alpine snow and ice was also expected at the peak time. There is usually no isotopic fractionation during snowfalls as the solid phase does not exchange isotopes with the atmospheric moisture; and snowpacks tend to conserve the isotopic composition of the cloud moisture with an elevated d-excess value (Gat et al., 2001). The value of d-excess varies locally and was shown to correlate with the physical conditions such as relative humidity, air temperature and sea surface temperature of the oceanic source area of the precipitation moisture (Merlivat and Jouzel, 1979). Thus the waters would be expected to to be more enriched with heavy isotopes and with an elevated d-excess if the streams were heavily recharged by meltwaters, and this is not the case in this work with Aqu River as possibly an exception (Table 3). Because of the heavy and frequent rainfalls, the ground water contribution to the streams is also considered to be insignificant. The "catchment isotope effect" (Rozanski et al., 2001) in the region during the sampling times was such the isotopes of the steam waters may be considered having essentially the same composition as those in the precipitation waters.

As noted earlier that the isotopic ratios $\left(\delta^{2} \mathrm{H}\right.$ and $\delta^{18} \mathrm{O}$ values $)$ are distributed quite evenly along the GMWL in Figure 2 (when the data from the Yellow River basin are excluded, see below for details). This may indicate that, as the stream waters were primarily of meteoric origin, the rain moisture may originate primarily from a single remote location and rainfalls formed along the way with different distances of moisture transport. Recently, Wang et al. (2016) used the entropy analysis method of stable isotopes in precipitation to study the monsoon systems in China, found that in southern China, the water vapor is mainly supplied by the Indian monsoon. "one stream of the Indian monsoon (I1) passes eastward from the southwestern border of China and then turns to the northeast of the south central China before reaching eastern China, where its intensity weakens after producing heavy rainfalls." However, the authors also recognized the impeding effect of the Himalayas that impedes the movement of the Indian monsoon from the south to north and the movement of the winter monsoon from the north to south (Wang et al., 2016). 


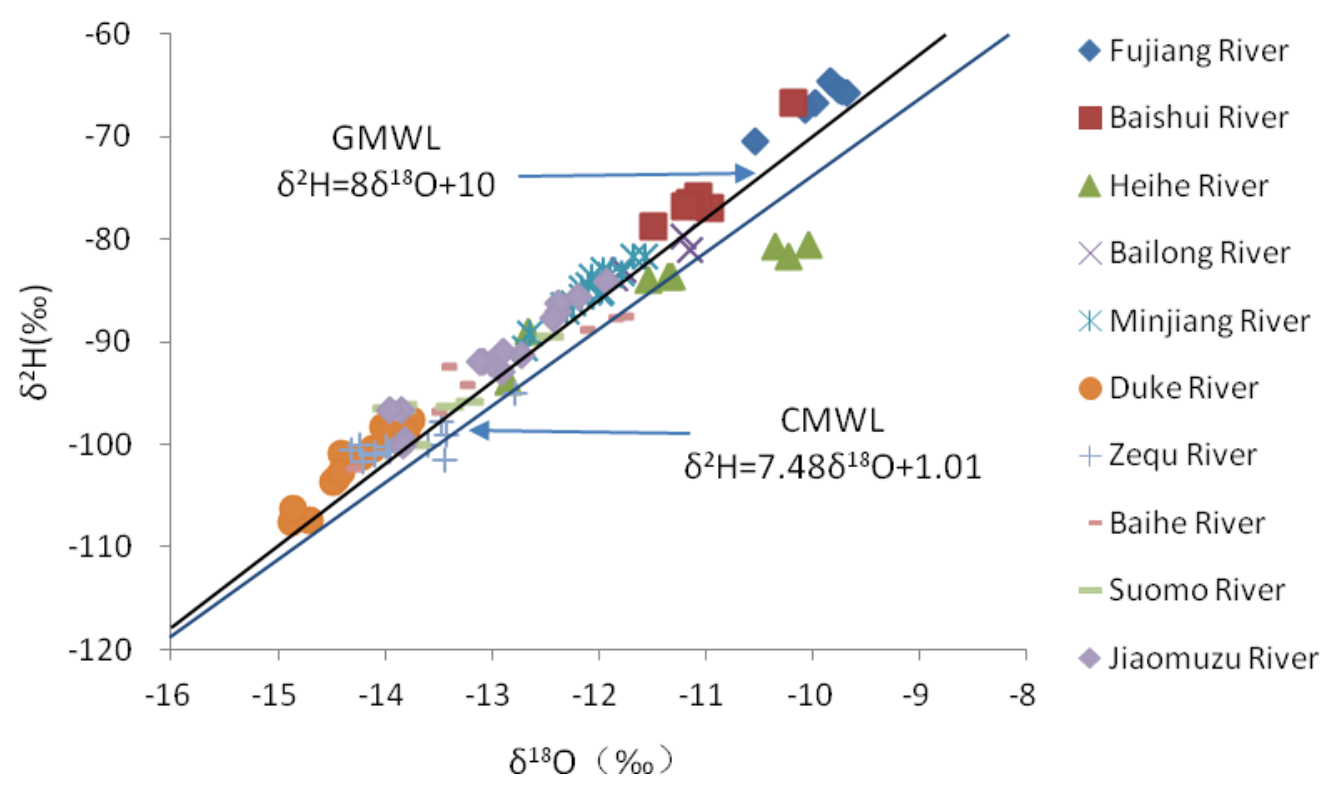

Figure 2. Diagram of hydrogen and oxygen isotopic ratios $\left(\delta^{2} H v s . \delta^{18} \mathrm{O}\right)$ for all water samples analyzed in this study. Note that the upper line represents the global meteoric water line

$(G M W L)$, and the lower line represents the China meteoric water line (CMWL)

These observations are also supported by the d-excess data. In the study area the dvalues span a relatively large range from -0.25 to 15.33 with a mean of 11.30 (Table 3), which is close to the global average (Rozanski et al., 1993). In examining the d-values, no apparent anomalies nor any reasonable patterns (e.g. decreasing values when further away from alpine glaciers) could be found, suggesting a predominantly well-mixed, relatively homogeneous source for the river waters, and contributions from the melting of alpine snow and ice were likely insignificant. Lower d-values relative to the surrounding areas were found in the Heishui County region (Figure 3); this may be attributed to high evaporation in the region where abundant sunshine is available throughout the year and the landscape is characterized by interweaved high mountain ranges and deep valleys (elevation differential as much as 1,000-2,000 $\mathrm{m}$ ). This unique combination of climatic and geographic conditions gave result to widely uneven precipitations and large temperature swings between day and night in the Heishui region. However, the rather low d-values may not be fully counted for by the evaporation effect; it is suspected that some water component previously affected by evaporation and stored in the riparian zone might have been pushed into the streams by the newly fallen precipitation through infiltration and hyporheic flow (National Research Council, 2002). The lower d-values found in the Heihe River and Beihe River area will be further discussed in a later section. 


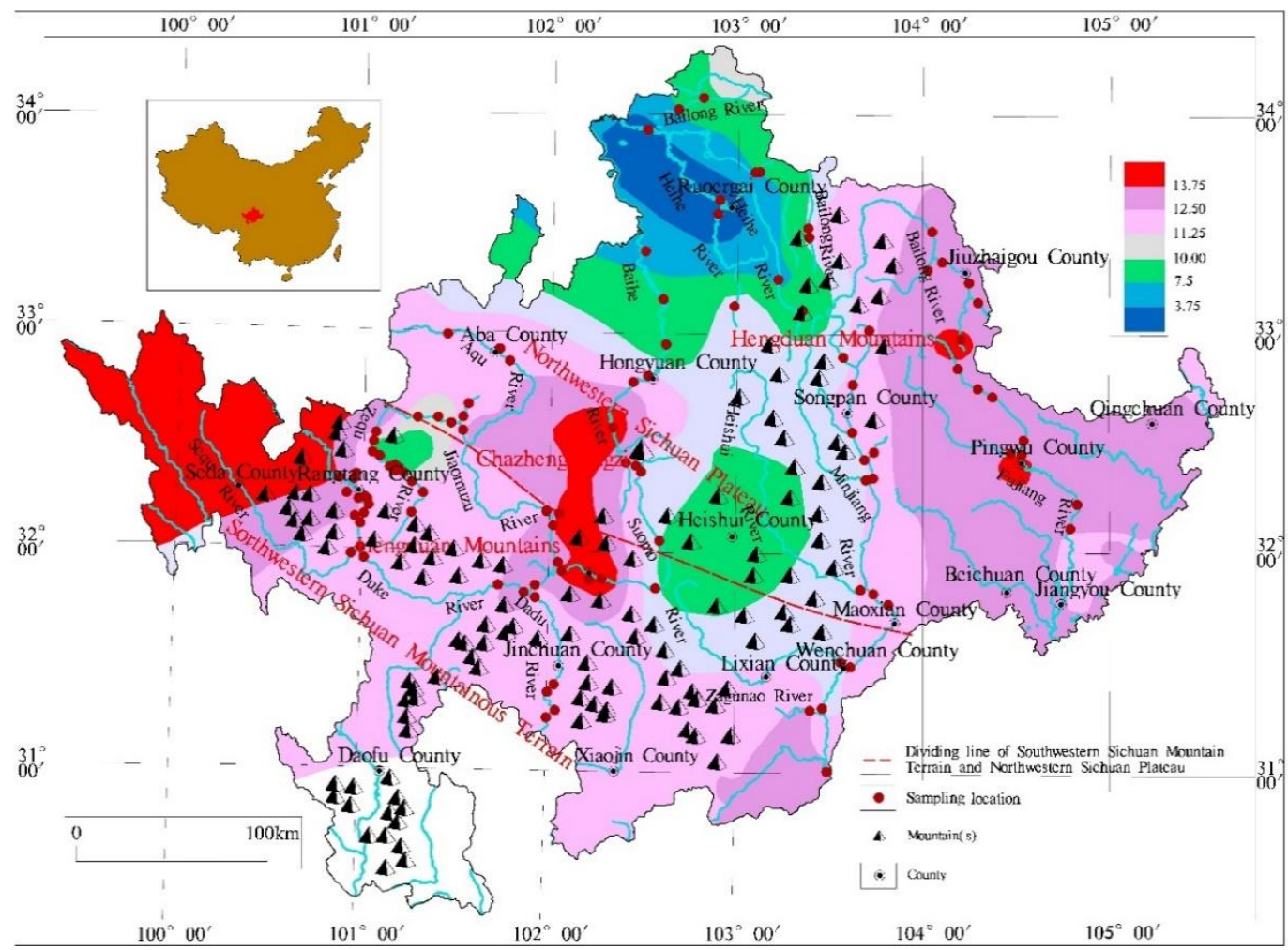

Figure 3. Spatial distribution of d-excess in the study area

\section{Effects of temperature, altitude and continentality}

The stable isotope ratios $\delta^{2} \mathrm{H}$ and $\delta^{18} \mathrm{O}$ are shown in Figures 4 and 5 as mapped contours through interpolation. In examining the contours in both figures, it is noted that there is a general trend: both ${ }^{2} \mathrm{H}$ and ${ }^{18} \mathrm{O}$ become progressively more depleted from east to west across the region. The study area is located inland at the west margin of the south China (SC) region and near the Tibet (TP) and north China (NC) regions according to Liu et al. (2014). The precipitation moisture of this area has a complex origin and is composed of components from the South China Sea, the Pacific and Indian Oceans, and local evaporation and circulation. This complex situation may be visually appreciated by the back-trajectories of the air masses on June 30 and July 4, 2010 and 2011 from two selected locations near the center of the studied area depicted in Figure 6, produced using the HYSPLIT transport and dispersion model (Stein et al., 2015; Rolph, 2016). In this region, the air mass has a general trend of undergoing progressive rainout of heavy isotopes during the pole-ward (latitude effect) and westward (continental effect) atmospheric transport (Liu et al., 2014). However, the southwesterly monsoon from the Indian Ocean may be effectively obstructed from reaching here by the Qinghai-Tibet Plateau, this is supported by studies such as Liu et al. (2007, 2014). It is postulated that the moisture for precipitation in this region originated primarily from the Pacific Ocean and the South China Sea during a period shortly prior to the sample campaigns. That is, the moisture air masses traveled mainly from east to west, isotopically enriched rain 
formed and fell from diminishing moisture mass and the residual moisture became progressively depleted in heavy isotopes with respect to earlier rains from the same cloud. This westerly continental effect explains well the observed isotope ratio contours seen in Figures 4 and 5, where no apparent pole-ward isotopic fractionation pattern is observed which is perhaps due to the ineffectiveness of the southwesterly monsoon in penetrating the Qinghai-Tibet Plateau (Liu et al., 2007, 2012).

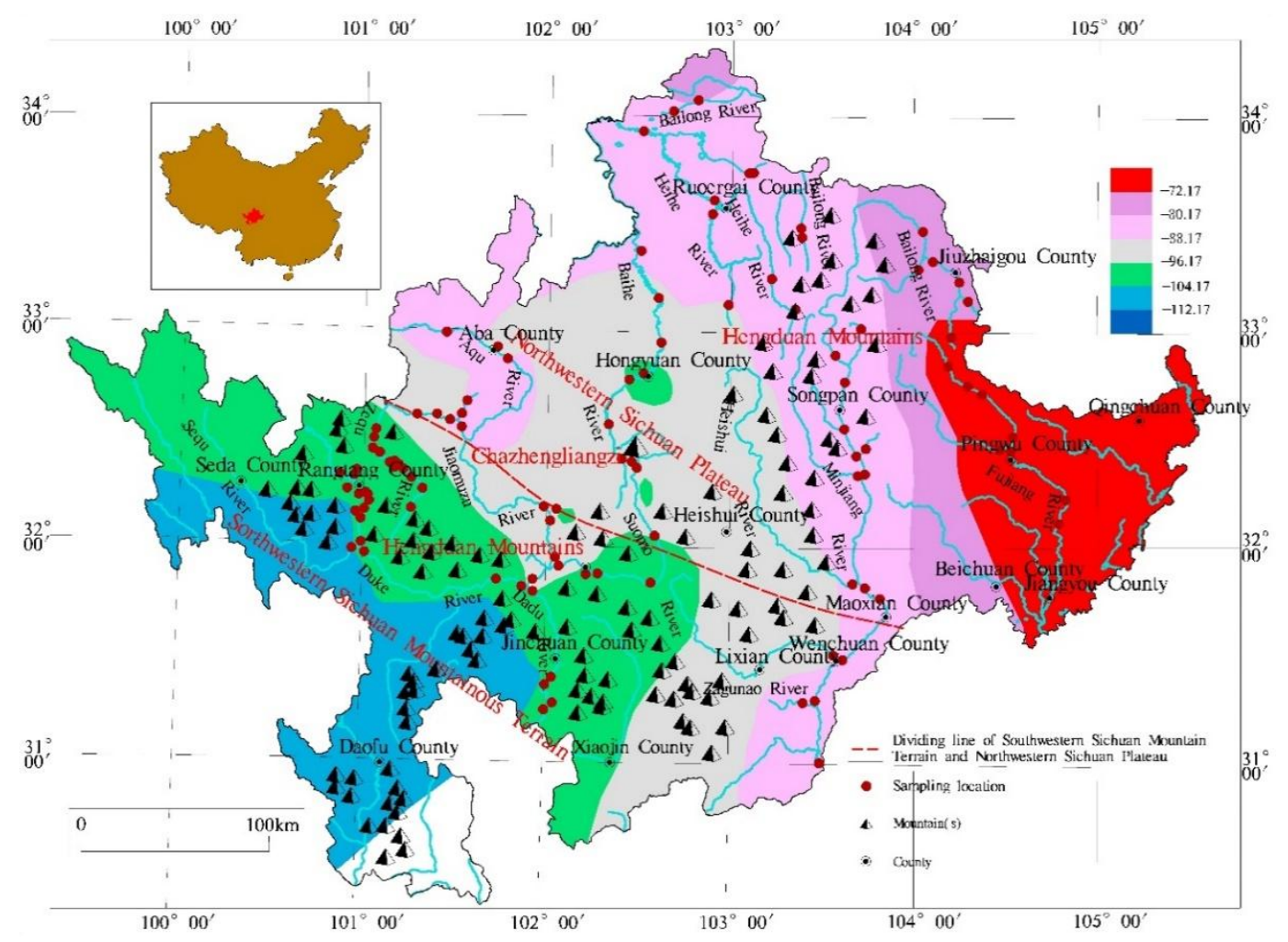

Figure 4. Spatial zonation of $\delta^{2} H$ in the study area

This noted general trend of isotopic composition change from east to west due to continental effect is fundamentally governed by temperature change. With decreasing temperature, rainfalls becomes more depleted in the heavier isotopes, ${ }^{2} \mathrm{H}$ and ${ }^{18} \mathrm{O}\left({ }^{2} \mathrm{H}\right.$ and ${ }^{18} \mathrm{O}$ are linearly correlated). Similar effects have been shown with increasing elevation and increased distance from the equator, both of which correspond to lower temperatures (Bowen et al., 2005b; Terzer et al., 2013). Our statistical analysis shows that both $\delta^{2} \mathrm{H}$ and $\delta^{18} \mathrm{O}$ are positively correlated with temperature, the Pearson productmoment correlation coefficients 0.492 and 0.517 for $\delta^{2} \mathrm{H}$-temperature and $\delta^{18} \mathrm{O}$ temperature, respectively, were obtained. Some early work (e.g., Zhang and Wu, 2007) suggests that the correlation between isotopic fractionation and temperature tends to be stronger when the temperature is lower.

Though the general zonation of $\delta^{2} \mathrm{H}$ and $\delta^{18} \mathrm{O}$ in the region (Figures 4 and 5) is believed to be governed by continentality, with increasing altitude the elevation and 
other effects (e.g. amount effect) are superimposed on the continental effect and might become predominant resulting in a local enrichment of the heavier isotopes. This may be observed in Figure 5 where both ${ }^{2} \mathrm{H}$ and ${ }^{18} \mathrm{O}$ are noticeably more depleted near Hongyuan presumably due to high altitude. Notwithstanding the altitude effect, the other factors including the amount effect (Dansgaard, 1964) and anthropogenic effect may also have played a role that should be fully investigated. For example, the east part of the study area is more densely populated and economically more developed; the increased anthropogenic activities including large amount of agricultural consumption of surface waters might have cut down the water runoff volumes and augmented natural evaporation and transpiration in the area, resulting in a more arid-like climate which in turn resulted in heavier isotopes relatively enriched (Figures 4 and 5).

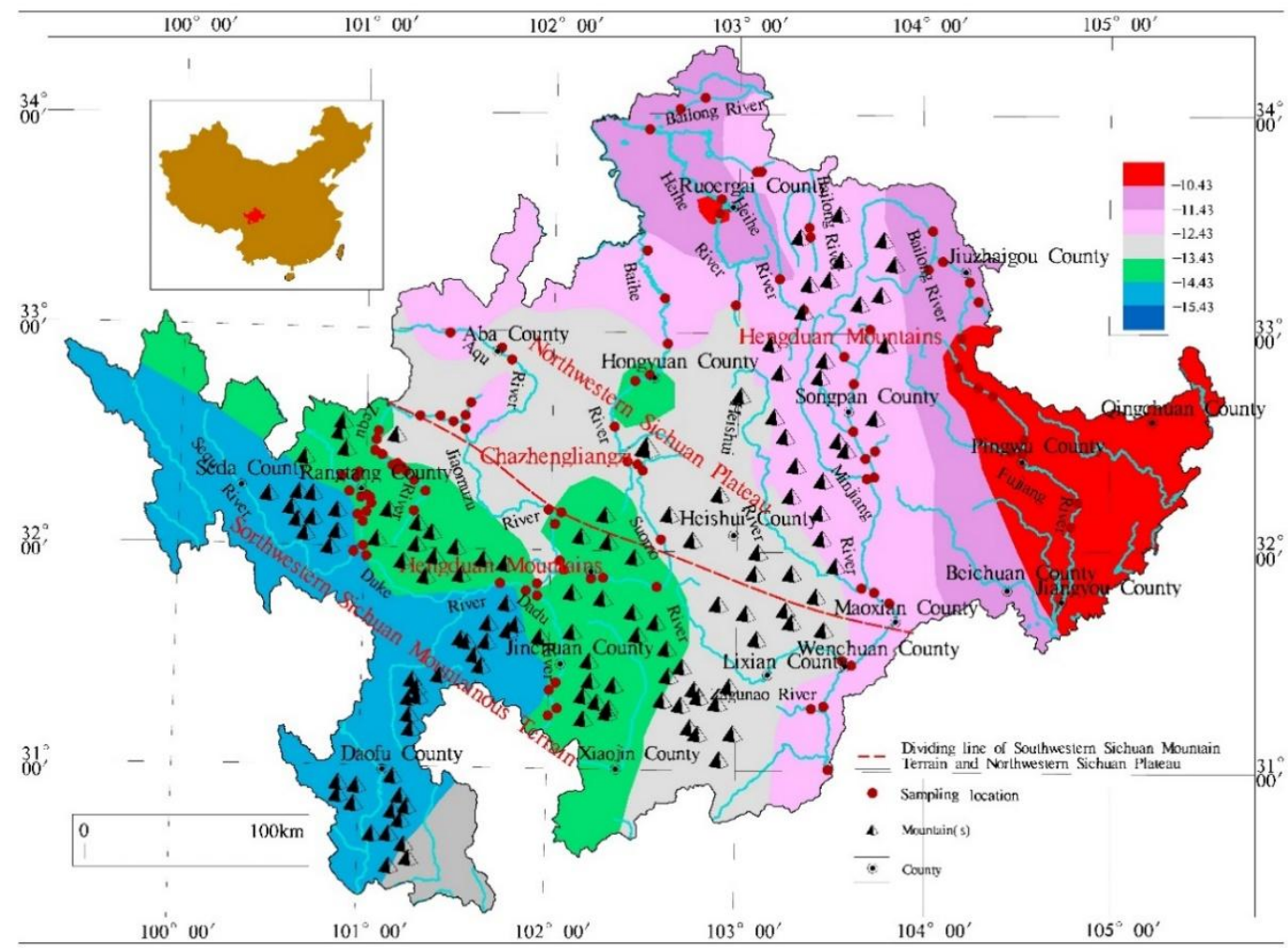

Figure 5. Spatial zonation of $\delta^{18} \mathrm{O}$ in the study area

Long-term data sets are necessary to fully understand the processes of water cycles because seasonal and climate changes can be significant (Stumpp et al., 2014). For this reason, the results reported in this work may be regarded as a snapshot of the area's water cycle processes at the wettest time of a year and much of the discussion should be taken in this context. As seasonal variations are expected to be greater for rivers that are mainly recharged by surface runoff from recent precipitations (Rozanski et al., 2001) such as the rivers in this study, more systematic sampling and investigations are necessary to fully understand the area's runoff isotope hydrology. 

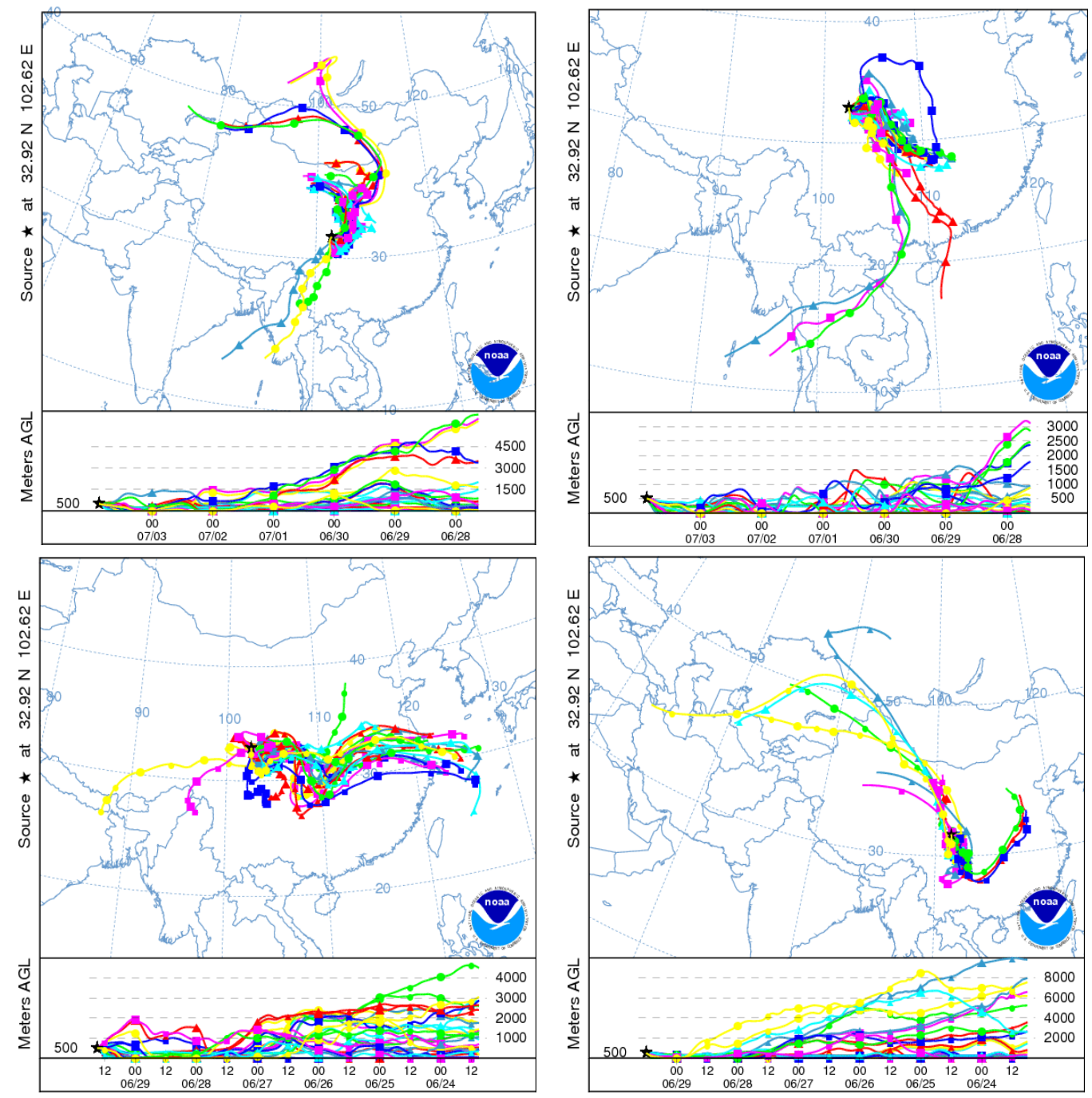

Figure 6. Week-long back trajectories of air masses on June 30 (bottom) and July 4 (top), 2010 (left) and 2011 (right) at 2 selected locations near the center of the study area

\section{Isotope distinction between the drainage basins of Yangtze River and Yellow River}

The meteoric water line specific to a certain location is controlled by local climatic factors including the oceanic moisture source and secondary processes affecting the isotopic composition of water vapor such as evaporation and re-circulation of moisture from large water bodies (Clark and Fritz, 1997). These factors together define a particular local meteoric water line (LMWL). A closer examination of Figure 2 reveals that some data points deviate appreciably from the GMWL which otherwise represents the stable hydrogen and oxygen isotope ratio data quite well. However, when only the data from the Yangtze River basin are plotted in Figure 7, a single LMWL is obtained: $\delta^{2} \mathrm{H}=8.06 \delta^{18} \mathrm{O}+12.69$ with $\mathrm{R}^{2}=0.98$, which is almost identical to the GMWL as revised by Rozanski et al. (1993): $\delta^{2} \mathrm{H}=8.17 \delta^{18} \mathrm{O}+10.35$, or by Gat et al. (2001): $\delta^{2} \mathrm{H}=7.8973{ }^{18} \mathrm{O}+9.0133$. This is indicative of the fact that heavy and frequent rainfalls prior to our sampling in the region had rendered the stream waters resemble the 
rainwaters so closely, and the streams in the Yangtze River drainage basin were recharged and maintained mainly by the rainfalls and the surface runoff. The lower the relative humidity is, the faster the evaporation rate would be and the greater the kinetic fractionation becomes. Humidity affects hydrogen and oxygen fractionations differently such that the slope of the evaporation line would vary due to changes in relative humidity. At very low relative humidity $(<25 \%)$, the slope of the evaporation line would be close to 4 ; for moderate relative humidity ( $25 \%$ to $75 \%$ ) the slope would be between 4 and 5; only for relative humidity above $95 \%$ would the slope approach 8, i.e., the slope of the meteoric water line (Clark and Fritz, 1997). Therefore, from Figure 7 it is inferred that humid conditions likely prevailed with relative humidity above $95 \%$ much of the time in the region. For a comparison, Liu et al. (2014), based on 928 groups of precipitation data, reported a Chinese Meteoric Water Line (CMWL) as $\delta^{2} \mathrm{H}=7.48 \delta^{18} \mathrm{O}+1.01$, as also shown in Figure 7. It appears that there is a fair amount of difference between our local water line (i.e., LMWL) and the CMWL; however, considering our data range is relatively very narrow when compared to the data used for deriving the CMWL (Liu et al., 2014), the difference is not that significant. Nevertheless, it is noted that our data are systematically located above the CMWL, which is reflected by the relatively big difference in the d-values (12.69 vs. 1.01) indicating that the source of vapor for the area's precipitation was likely unique, i.e., sufficiently different from the bulk from that the CMWL was derived.

As noted earlier, the rivers belonging to the Yangtze River basin have rather different characteristics of stable hydrogen and oxygen isotopes from west to east across the area (Table 3). In the west of the Northwestern Sichuan Plateau the rivers including the Duke River, the Zequ River, the Suomo River, and the Jiaomuzu River are relatively enriched in the light isotopes; an exception is the Aqu River, a tributary of the Jiaomuzu River, which is relatively enriched in heavy isotopes and its d-values are lower than the other rivers. In comparison, the rivers in the east of the Northwestern Sichuan Plateau including the Fujiang River, the Minjiang River, and the Baishui River are relatively enriched in heavy isotopes. As discussed above, the isotope ratios change from east to west likely due to the continental effect, whereas the Aqu River was probably also appreciably recharged by alpine lake waters which were collection of glacier meltwater. However, the hydrogen and oxygen isotope ratios of the Fujiang River and the Minjiang River also have a trend of increasing from north to south possibly due to the altitude effect as the elevations increase appreciably (by as much as 2,000 m) from north to south along the two rivers. Besides, these two rivers have been more significantly affected by anthropogenic activities that may have added additional impact to the hydrogen and oxygen isotope ratios. For example, the water samples taken from the lower reach of the Minjiang River are slightly enriched in heavy isotopes with $\delta^{2} \mathrm{H}$ $/ \delta^{18} \mathrm{O}$ as $-70.4 /-10.54$ and $-81.7 /-11.69$ respectively from two locations $(500 \mathrm{~m}$ downstream of the Yilixiang Hua'neng Hydro Station, and downstream after the Heishui River enters the Minjiang River), compared to the values of -90.6/-12.69 in its upper reach (upstream of the Zagu'nao River Hydro Station). 


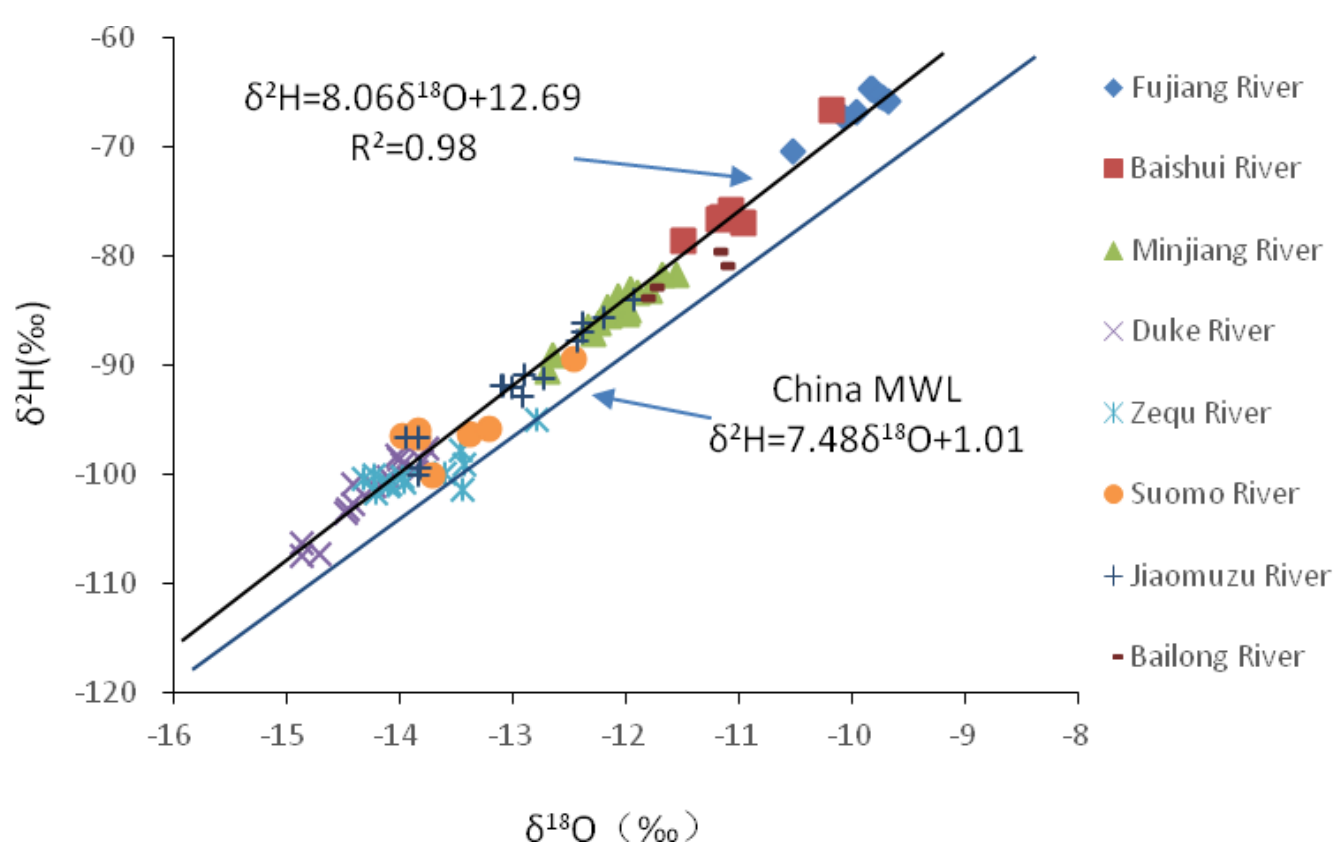

Figure 7. $\delta^{2} H$ vs. $\delta^{8} O$ diagram for stream water samples collected from the Yangtze River basin

The relatively small area in the northern part of the study area (Figure 1) including the Heihe River and the Baihe River catchments belongs to the Yellow River drainage basin. When the stable hydrogen and oxygen isotope ratios from this area only (i.e., the data points that deviate from the GMWL in Figure 2) were plotted as shown in Figure 8, a local evaporation line (LEL) was obtained: $\delta^{2} \mathrm{H}=4.77 \delta^{18} \mathrm{O}-30.99$ with $\mathrm{R}^{2}=0.93$, which differs appreciably from the GMWL (Rozanski et al., 1993; Hoefs, 2009), the CMWL (Liu et al., 2014), and the LMWL of the Yangtze River basin (Figure 7). The much smaller slope (4.77) is usually an indication of a more arid climate (i.e., lower relative humidity) (Gat, 1996).

The $\delta^{2} \mathrm{H}$ and $\delta^{18} \mathrm{O}$ values of water samples from the Yellow River basin range from -100.1 to -79.7 and from -13.98 to -10.03 , respectively, varying over wider ranges (particularly the Heihe River) in comparison with those from the Yangtze River basin. In particular, the Heihe River and the Baihe River extend hundreds of kilometers from south to north before eventually flowing into the Yellow River, and their hydrogen and oxygen isotope compositions exhibit a general trend of increasingly more depleted in heavy isotopes. The d-excess data are presented as contoured lines in Figure 3; the dvalues of water samples from this area are noticeably lower with a minimum of -0.25 , also exhibiting a trend of decreasing from the upper reach to the lower reach of the rivers (i.e. form south to north). According to Gat (1996), in more arid areas evaporation from the falling rain droplets beneath the cloud base or from surface waters can result in the enrichment of the heavy isotopes in the remnant raindrops along the evaporation line, the resulting precipitation would show a smaller d-value 
than at the cloud base. Therefore, even though both this small area belonging to the Yellow River basin and the east part of the study area display some isotopic features in common (e.g., relatively less depleted in heavy isotopes and smaller d-values), the underlying governing factors are different. This area is at or near the north China (NC) region where $\delta^{18} \mathrm{O}$ was shown to be closely related to the wind directions, relative humidity and vapor pressure; this is distinctively different from the case of the SC region where $\delta^{18} \mathrm{O}$ was shown to depend on the remaining fraction of the vapor phase in an isothermal condensation process (Liu et al., 2014).

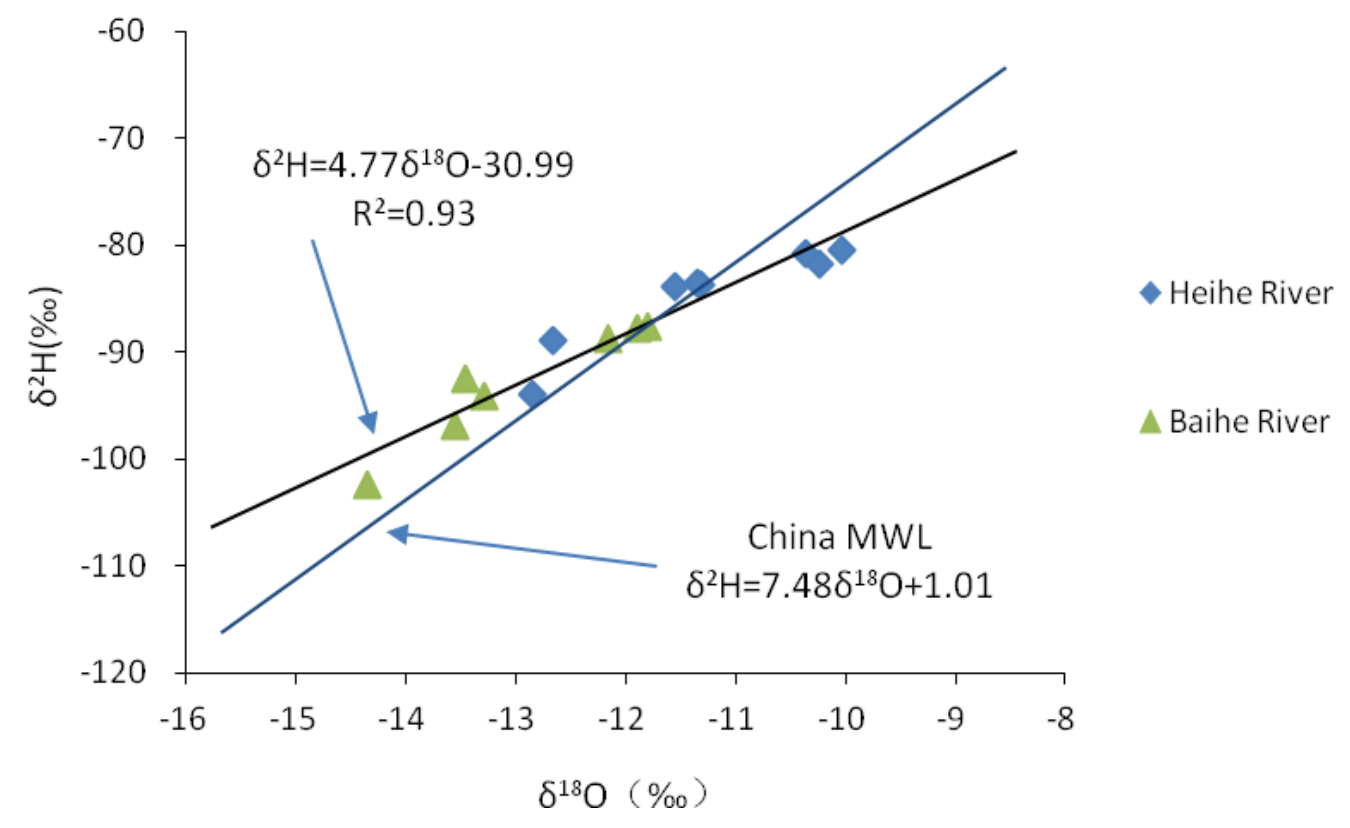

Figure 8. $\delta^{2} H$ vs. $\delta^{18}$ O diagram for water samples collected from the Yellow River basin

\section{Mixing of some major rivers}

When two or more tributaries merge to form a mainstream, the mixing ratio from each can be quantitatively calculated based on the isotopic mass balance principle. The fundamental equation ( $E q$. l) can be written as:

$$
r_{T} m_{T}=r_{1} m_{1}+r_{2} m_{2}+\cdots+r_{n} m_{n}
$$

where $r$ is the fractional abundance of a stable isotope, $m$ the molar quantity of the stable isotope, and the subscripts $T$ and $n$ denote, respectively, the merged mainstream and a tributary. When 2 tributaries merge to form a mainstream, the mass balance equation (Eq. 2) for ${ }^{18} \mathrm{O}$ can be written as:

$$
r_{18} m_{18}=r_{18} o_{1} m_{18} o_{1}+r_{18} o_{2} m_{18} o_{2}
$$


where (Eq. 3):

$$
r_{18}=\frac{m_{18} 0}{m_{18}+m_{16} 0}
$$

For all practical purposes, $r_{18}$ may be substituted by $\delta^{18} \mathrm{O}$ and $E q .2$ becomes (Eq. 4):

$$
\delta^{18} O_{m_{18}}=\delta^{18} O_{1} m_{18} O_{1}+\delta^{18} O_{2} m_{18} o_{2}
$$

Eq. 4 is not exact because of the approximation of the $\delta$ values for $r$ values. The errors due to this approximation have been carefully evaluated and proven negligible for all practical applications (Fry, 2003). Eq. 4 can be rearranged (note that $\left.m_{18}=m_{18}{ }_{01}+m_{18} o_{2}\right)$ to read as (Eq. 5):

$$
\frac{m_{18} o_{1}}{m_{18}}=\frac{\delta^{18} o-\delta^{18} o_{2}}{\delta^{18} o_{1}-\delta^{18} o_{2}}
$$

where $\frac{m_{18_{0}}}{m_{18_{0}}}$ is the fraction contribution of tributary 1 to the mainstream.

The Dadu River is the most important tributary of the Minjiang River that in turn is a major tributary of the Yangtze River. The Dadu River has three sources: the east source Suomo River, the west source Duke River, and the main source Zumuzu River. At the confluence where the Sequ River merges into the Duke River, samples were taken and analyzed, and the following $\delta^{18} \mathrm{O}$ values were obtained: $-14.9 \%$ o, $-14.0 \%$ and $-14.2 \%$, respectively, from Sequ River, upstream of Duke River, and downstream of Duke River. Using Eq. 5 it is calculated that $\frac{m_{1 \mathrm{~B}_{1}}}{m_{1 \mathrm{~B}_{0}}}$ equals 0.28 , i.e. the component from the Sequ River to the Duke River was $28 \%$ at the time of sampling.

Further upstream of the Sequ River, the Angkegou Stream in Rangtang is another tributary of the Duke River, but is much smaller than the Sequ River. The following $\delta^{18} \mathrm{O}$ values were obtained around the point where the Angkegou Stream enters the Duke River: $-14.9 \%$, $-13.8 \%$ and $-13.8 \%$, from the Angkegou Stream, upstream and downstream of the Duke River, respectively. Apparently, given the precision of our isotope analysis, it is not feasible to calculate the contribution of the Angkegou Stream to the Duke River using the oxygen isotope ratios with any confidence.

The Suomo River and the Duke River merge at Baiwan and then flow into the Dadu River. Near the joint, the $\delta^{18} \mathrm{O}$ values were obtained as $-13.1 \%$, $-14.4 \%$ and $-13.8 \%$, respectively, for the water samples from the Suomo River, Duke River and the Dadu River. The contribution of the Duke River to the Dadu River was calculated to be $55 \%$ and Suomo River to the Dadu River to be $45 \%$.

The calculations based on mass balance are valid only when the tributary waters are fully mixed in the mainstream. Using the same method, the contribution of Ake River to 
Ma'erqu (a secondary tributary of the Yangtze River, upper reach of the Jiaomuzhu River) was calculated to be $75 \%$; but it was noted during field work that the Ake River flow was too small and its contribution to the Ma'erqu River could not possibly be that high. This apparent error was likely due to the fact that the sample taken from downstream Ma'erqu River with $\delta^{18} \mathrm{O}=-12.4$ was most likely not representative of the well-mixed water body due to physical difficulty in sampling: a steep cliff prevented the sample from being taken near the center of the Ma'erqu River. Instead, the sample was taken near the cliff where the water was suspected to be predominantly from the Ake River $\left(\delta^{18} \mathrm{O}=-12.2\right)$, and a thorough mixing with the Ma'erqu River water had not yet achieved. Note that these river mixing calculations are approximate, as the uncertainties in the $\delta$-values ( $\pm 0.2 \%$ and $\pm 2.0 \%$ for $\delta^{18} \mathrm{O}$ and $\delta^{2} \mathrm{H}$, respectively) are not evaluated.

\section{Conclusions}

In general, the stable oxygen and hydrogen isotope ratios are correlated with the distance to the east coast of China, in agreement with a continentality model. That is, the stream waters were gradually depleted in heavy isotopes from east to west in the area studied. This phenomenon is attributed to the successive rainfalls from the same moisture cloud and the preservation of isotopic signature in the runoff from the precipitations. Local deviations from this general trend may be explained by the elevation effect and some anthropogenic factors.

The $\delta^{2} \mathrm{H}$ and $\delta^{18} \mathrm{O}$ data of the samples from the Yangtze River basin, which covers the majority of the study area, align well with the CMWL and particularly with the GMWL, suggesting that the stream waters in this area were primarily of meteoric origin (including ice and snow melting) with a regional weak evaporation effect prevailing. However, the data from a relatively small area belonging to the Yellow River basin are characterized by an appreciably flatter slope of the isotope water line, suggesting that the waters had undergone significant evaporation due to kinetic fractionations of isotopes in a more arid climate. These observations are also supported by the d-excess values.

Since the samples were taken during summer time, this study provides a snapshot of the region's river hydrology during the rainy season. As the stable isotope ratios can vary greatly both over time and space, for a more complete understanding of the local river hydrology more systematic sampling and analysis over time will be necessary. Precipitation samples should be collected and analyzed together with the stream water samples so that a direct correlation between the runoff waters and precipitations could be more firmly established. Nevertheless, the stream isotope data presented in this work should be valuable to those who are concerned with the TRH eco-system or, more broadly, the eco-environment of the Qinghai-Tibet Plateau. 
Acknowledgements. The field and laboratory work was funded by the Geological Survey of China (Grant No. 1212011121156) and the National Natural Science Foundation of China (Grant No. 41373120). The funding to P. Pan from Sichuan Province through the Overseas Recruitment Program is instrumental for the final stage of the project. Several colleagues including Zhang Cong, Wei Fei, and Zhang Hang are acknowledged for their assistance during the execution of the project and the preparation of the manuscript. The authors gratefully acknowledge the NOAA Air Resources Laboratory (ARL) for the provision of the HYSPLIT transport and dispersion model and READY website (http://www.ready.noaa.gov) used in this publication.

\section{REFERENCES}

[1] Abbott, M. D., Lini, A., Bierman, P. R. (2000): $\delta^{18} \mathrm{O}, \delta \mathrm{D}$ and ${ }^{3} \mathrm{H}$ measurements constrain groundwater recharge patterns in an upland fractured bedrock aquifer, Vermont, USA. - J. Hydrol. 228: 101-112.

[2] Adomako, D., Maloszewski, P., Stumpp, C., Osae, S., Akiti, T. T. (2010): Estimating groundwater recharge from water isotope $\left(\delta^{2} \mathrm{H}, \delta^{18} \mathrm{O}\right)$ depth profiles in the Densu River basin, Ghana. - Hydrol. Sci. J. 55(8): 1405-1416.

[3] Avis, C. A., Weaver, A. J., Meissner, K. J. (2011): Reduction in areal extent of highlatitude wetlands in response to permafrost thaw. - Nat. Geosci. 4(7): 444-448.

[4] Blasch, K. W., Bryson, J. R. (2007): Distinguishing sources of ground water recharge by using $\delta^{2} \mathrm{H}$ and $\delta^{18} \mathrm{O}$. - Ground Water 45(3): 294-308.

[5] Bowen, G. J., Wassenaar, L. I., Hobson, K. A. (2005a): Global application of stable hydrogen and oxygen isotopes to wildlife forensics. - Oecologia 143: 337-348.

[6] Bowen, G. J., Winter, D. A., Spero, H. J., Zierenberg, R. A., Reeder, M. D., Cerling, T. E., Ehleringer, J. R. (2005b): Stable hydrogen and oxygen isotope ratios of bottled waters of the world. - Rapid Commun. Mass Spectrom. 19: 3442-3450.

[7] Brooks, J. R., Barnard, H. R., Coulombe, R., McDonnell, J. J. (2010): Ecohydrologic separation of water between trees and streams in a Mediterranean climate. - Nat. Geosci. 3: $100-104$.

[8] Burgoyne, T. W., Hayes, J. M. (1998): Quantitative production of $\mathrm{H}_{2}$ by pyrolysis of gas chromatographic effluents. - Anal. Chem. 70: 5136-5141.

[9] Buttle, J. M., McDonnell, J. J. (2004): Isotope tracers in catchment hydrology in the humid tropics. - In: Bonell, M., Bruijnzeel, L. A. (ed.) Forests, Water and People in the Humid Tropics Past, Present and Future Hydrological Research for Integrated Land and Water Management, pp. 770-789. Cambridge University Press, Cambridge.

[10] Clark, I., Fritz, P. (1997): Environmental Isotopes in Hydrogeology. - Lewis Publishers, Boca Raton.

[11] Craig, H. (1961): Isotopic variations in meteoric waters. - Science 133: 1702-1703.

[12] Dansgaard, W. (1964): Stable isotopes in precipitation. - Tellus 16: 436-468.

[13] Fry, B. (2003): Steady state models of stable isotopic distributions. - Isotopes Environ. Health Stud. 39: 219-232.

[14] Gao, J., Li, X., Cheung, A., Yang, Y. (2013): Degradation of wetlands on the QinghaiTibet Plateau: a comparison of the effectiveness of three indicators. - J. Mt. Sci. 10(4): 658-667.

[15] Gat, J. R. (1996): Oxygen and hydrogen isotopes in the hydrologic cycle. - Annu. Rev. Earth Planet. Sci. 24: 225-262.

[16] Gat, J. R., Mook, W. G., Meijer, H. A. J. (2001): Environmental isotopes in the hydrologic cycle. Principles and applications. Vol. II: Atmospheric water. - IHP-V, Technical Documents in Hydrology, No. 39, UNESCO, Paris.

[17] Hoefs, J. (2009): Stable Isotope Geochemistry, 6th ed. - Springer-Verlag, Berlin.

[18] Kendall, C., McDonnell, J. J. (1998): Isotope Tracers in Catchment Hydrology. - Elsevier, Amsterdam. 
[19] Li, H., Liu, G., Fu, B. (2012): Estimation of regional evapotranspiration in alpine area and its response to land use change: a case study in Three-River Headwaters Region of Qinghai-Tibet Plateau, China. - Chin. Geogra. Sci. 22(4): 437-449.

[20] Liu, J., Song, X., Yuan, G., Sun, X., Yang, L. (2014): Stable isotopic compositions of precipitation in China. - Tellus B 66: 22567, http://dx.doi.org/10.3402/tellusb.v66.22567.

[21] Liu, X., Song, X., Xia, J., Yu, J., Zhang, X. (2007): Characteristics of hydrogen and oxygen isotopes and preliminary analysis of vapor source for precipitation in Chabagou catchment of the Loess Plateau. - Resources Science 29: 59-66 (in Chinese with English abstract).

[22] Liu, Z., Bowen, G. J., Welker, J. M. (2010): Atmospheric circulation is reflected in precipitation isotope gradients over the conterminous United States. - J. Geophys. Res. 115: D22120.

[23] Merlivat, L., Jouzel, J., (1979): Global climatic interpretation of the deuterium-oxygen 18 relationship for precipitation. - J. Geophys. Res. 84: 5029-5033.

[24] National Research Council (2002): Riparian Areas: Functions and Strategies for Management. - The National Academies Press: Washington, DC. https://doi.org/10.17226/10327.

[25] Paul, D., Skrzypek, G., Fórizs, I. (2007): Normalization of measured stable isotopic compositions to isotope reference scales - a review. - Rapid Commun. Mass Spectrom. 21(18): 3006-3014.

[26] Qi, D. C., Li, G. Y. (2007): Status, causes and protection countermeasures of wetland degradation in Maqu county in the Upper Yellow River. - Wetland Science 5(4): 341-347 (in Chinese with English abstract).

[27] Richelle, M., Darimont, C., Piguet-Welsch, C., Fay, L. B. (2004): High-throughput simultaneous determination of plasma water deuterium and 18-oxygen enrichment using a high-temperature conversion elemental analyzer with isotope ratio mass spectrometry. Rapid Commun. Mass Spectrom. 18: 795-798.

[28] Rolph, G. D. (2016): Real-time Environmental Applications and Display sYstem (READY) website (http://www.ready.noaa.gov). - NOAA Air Resources Laboratory, College Park, MD.

[29] Rozanski, K., Araguás-Araguás, L., Gonfiantini, R. (1993): Isotopic Patterns in Modern Global Precipitation. - In: Swart, P. K. et al. (ed.) Climate Change in Continental Isotopic Records (Geophys. Monogr. Ser. 78), pp. 1-36, AGU, Washington, DC.

[30] Rozanski, K., Froehlich, K., Mook, W. G. (2001): Environmental isotopes in the hydrologic cycle. Principles and applications. Vol. III: Surface water. IHP-V, Technical Documents in Hydrology, No. 39. - UNESCO, Paris.

[31] Shi, Z., Pan, P., Feng, Y., Kan, Z., Li, Z., Wei, F. (2016): Environmental water chemistry and possible correlation with Kaschin-Beck Disease (KBD) in northwestern Sichuan, China. - Environ. Int. 99: 282-292.

[32] Sjostrom, D., Welker, J. (2009): The influence of air mass source on the seasonal isotopic composition of precipitation, eastern USA. - J. Geochem. Explor. 102(3): 103-112.

[33] Stein, A. F., Draxler, R. R, Rolph, G. D., Stunder, B. J. B., Cohen, M. D., Ngan, F. (2015): NOAA's HYSPLIT atmospheric transport and dispersion modeling system. - Bull. Amer. Meteor. Soc. 96: 2059-2077, http://dx.doi.org/10.1175/BAMS-D-14-00110.1

[34] Stumpp, C., Klaus, J., Stichler, W. (2014): Analysis of long-term stable isotopic composition in German precipitation. - J. Hydrol. 517: 351-361.

[35] Terzer, S., Wassenaar, L. I., Araguás-Araguás, L. J., Aggarwal, P. K. (2013): Global isoscapes for $\delta^{18} \mathrm{O}$ and $\delta^{2} \mathrm{H}$ in precipitation: improved prediction using regionalized climatic regression models. - Hydrol. Earth Syst. Sci. 17: 4713-4728.

[36] Vachon, R., Welker, J., White, J., Vaughn, B. (2010): Moisture source temperatures and precipitation $\delta^{18} \mathrm{O}$-temperature relationships across the United States. - Water Resour. Res. 46(7): W07523. 
[37] Wang, G., Li, Y., Wang, Y., Chen, L. (2007): Typical alpine wetland system changes on the Qinghai-Tibet Plateau in recent 40 years. - Acta Geogr. Sin. 62(5): 481-491. (In Chinese with English abstract).

[38] Wang, T., Chen, J., Ling, L. (2016): Entropy analysis of stable isotopes in precipitation: tracing the monsoon systems in China. - Sci. Rep. 6: 30389, doi: 10.1038/srep30389. https://www.ncbi.nlm.nih.gov/pmc/articles/PMC4979205/pdf/srep30389.pdf.

[39] Welker, J. M. (2000): Isotopic (delta O-18) characteristics of weekly precipitation collected across the USA: an initial analysis with application to water source studies. Hydrol. Process. 14(8): 1449-1464.

[40] Zhang, Y. (ed. in chief) (1994): Quality Assurance Manual for Environmental Water Monitoring. - Chemical Industry Press, Beijing (in Chinese with English abstract).

[41] Zhang, Y., Wu, Y. (2007): Relationship between precipitation hydrogen and oxygen isotopes and temperature in mid- and upstream region of the Heihe River Basin. - Arid Land Geography 30 (1): 16-21 (in Chinese with English abstract).

[42] Zhao, Z., Liu, J., Shao, Q. (2010): Characteristic analysis of land cover change in nature reserve of Three River's source regions. - Scientia Geographica Sinica 30(3): 415-420, (in Chinese with English abstract). 